\title{
The rise and fall in the salience of race equality in higher education
}

\author{
Professor Andrew Pilkington, University of Northampton
}

\begin{abstract}
This chapter examines a twenty year period to explore the salience of race equality in higher education. While the dominant policy discourse has periodically drawn attention to the need to combat racial disadvantage, the only serious race equality strategy, following publication of the Macpherson report, was short lived and in the last decade race equality has virtually fallen off the policy agenda. And yet over the same period, research evidence accumulates to demonstrate that BME staff and students continue to experience considerable disadvantage. It is suggested that in the face of such evidence universities are remarkably complacent. Such complacency partly stems from the dominance in the academy and indeed of much of society of a liberal as opposed to radical perspective on equality. Universities typically see themselves as liberal and believe existing policies ensure fairness and in the process ignore adverse outcomes and do not see combating racial inequalities as a priority. This points in my view to the sheer weight of whiteness which will remain intact unless significant pressure is placed on universities to change. The chapter concludes by outlining two ideal typical approaches to the promotion of race equality and suggests that the period has witnessed the transition from an approach close to the first ideal type to an approach close to the second approach. Regardless of which approach is preferred, universities are urged to have no truck with a deficit model and to see it as their responsibility to take action to ensure more equitable outcomes.
\end{abstract}

\section{Introduction}

What initially prompted me to address the issue of race and higher education wasthe murder of a young black man, Stephen Lawrence in 1993 because of the colour of his skin. The subsequent flawed police investigation eventually led to an official inquiry chaired by Sir William Macpherson. The report published in 1999 was extraordinarily damning: 'The [police] investigation was marred by a combination of professional incompetence, institutional racism and a failure of leadership by senior officers' (Macpherson, 1999: Para 46.1). And the political response, as exemplified by the Home Secretary's response to the report, was equally forthright: 'In my view, any long-established, white-dominated organisation is liable to have procedures, practices and a culture that tend to exclude or to disadvantage non-white people' (Hansard, 1999: Col 391).

The acceptance by a senior judge and leading Minister of the charge of institutional racism was unprecedented and inaugurated what I have labelled 'a radical hour' when the state seemed to be serious about promoting race equality (Pilkington, 2014).

Prior to the Stephen Lawrence Inquiry, very little attention was paid to race and ethnicity in relation to higher education in the UK (Neal, 1998; Law et al., 2004; Pilkington, 2011). As one writer puts it, The university sector... remained relatively insulated from other policy developments in councils, schools, the health service and the police with regards to challenging racism and promoting ethnic and cultural diversity' (Law, 2003: 519). Such detachment was also evident in research where 'in contrast to the large amount of work on race and schooling in Britain, relatively little [had] been 
written on "race" and higher education' (Jacobs \& Hai, 2002: 171). The advent of the Labour government in 1997 and the subsequent publication of the Macpherson report provided a jolt to the sector. Renewed impetus was given to equality initiatives and the limitations of equal opportunity policies in generating cultural change and combating racial disadvantage were more widely recognised.

This chapter surveys the two decades since 1997 to examine how the higher education sector in general and one university in particular has addressed race and ethnicity. It will draw upon a growing research literature to evaluate the major policy initiatives. I shall argue that the salience of race equality which rose dramatically in the aftermath of the publication of the Macpherson report, and the government's response to it, has not been sustained. While new policy initiatives periodically emerge, what is remarkable in my view is the failure of the higher education sector in the last twenty years to transform the experience of Black and Minority Ethnic (BME) staff and students. Racial disadvantage remains stubbornly persistent, as we shall see.

\section{The increasing salience of race equality}

For a brief period in the first few years of the new millennium, the state exerted considerable pressure on universities to address race equality. Two issues in particular were highlighted in major research publications. The first related to staffing. A report published a few months after the Macpherson report in June 1999, pointed to disadvantages experienced by academic staff from minority ethnic groups (Carter et al, 1999). The disadvantages related to recruitment, employment status and career progression, with some BME staff reporting experiences of racial discrimination and harassment. A few years later, another major study pointed to disadvantages experienced by BME students. The latter were less likely to be found in old universities, more likely to drop out, less likely to be awarded good honours degreesand more likely to do less well in the labour market (Connor et al, 2004).

Acknowledging these to be the central issues in higher education pertaining to race, the state cajoled universities to address race equality through two strategies for higher education, notably those concerned with widening participation and human resources. The first sought to promote equality and diversity in the student body, while the second was concerned with promoting equal opportunities in staffing. While the specific mechanisms employed to promote widening participation and equal opportunities have changed over time, the annual funding letters from the government to the Higher Education Funding Council for England (HEFCE) reveal that these remain government 'priorities' (HEFCE, 2016). In addition to these colour blind strategies, the state also for a period required universities along with other public organisations to develop race equality policies and action plans following new race relations legislation in 2000.

How successful were these colour blind strategies in promoting race equality? However effective these strategies may have been in relation to other equality strands, they do not seem to have made significant inroads in combating race inequality.

The primary concern of widening participation strategies is social class. The result is that the needs of BME students have been of marginal concern to policy makers (AimHigher, 2006). The focus of policy on admissions to the sector as a whole glossed over the differentiated nature of the higher education sector and overlooked the different rates of return from gaining access to higher 
education (Reayet al, 2005). In particular it failed to address the fact that BME students, though well represented in the sector as a whole, are underrepresented in the more prestigious institutions and continue to be less likely than White students to gain good honours degrees. A study exploring in depth widening participation initiatives indicates that the sector generally prioritises pre-entry and access initiatives at the expense of interventions once students have entered HE' (Thomas et al, 2005: 193). This finding is significant and has adverse consequences for minority ethnic groups who are more likely to gain access to the sector but disproportionately face problems in succeeding.

Turning to strategies promoting equal opportunities, a series of audits reveal significant lacunae. One reveals that many key staff do not believe in the importance of EO (HEFCE 2005a), while other research indicates that many staff are in fact highly sceptical of the efficacy of equal opportunities policies (Deem et al 2005). Furthermore, analysis of university equal opportunities strategies identifies significant deficiencies in monitoring (HEFCE 2002/14, para. 143 in HEFCE, 2007) and in target setting (HEFCE 2003/37, para. 27 in HEFCE 2007). ). Since it has been widely recognised for a long time that an organisation intent on preventing or detecting racial discrimination needs to undertake both 'ethnic monitoring and the setting of targets' (Sanders 1998: 38), the evidence pointing to failures in data gathering and target setting suggest that many HEls have not take nequal opportunities policies seriously, at least when it comes to race. This suggestion is confirmed by official evaluations of human resources strategies which indicate that the implementation of equal opportunities strategies continued to exhibit a greater concern with gender than race issues (HEFCE 2005b). Previous research had indicated that equal opportunities policies in higher education tend to focus on gender rather than race (Neal 1998; Law et al 2004). The evidence above that the implementation of equal opportunities strategies entailed a greater concern with gender than race issues suggests that this prioritisation persists.

Let us turn to an approach that is explicitly concerned with race. The government's major response to the Macpherson report was a legislative initiative, the Race Relations (Amendment) Act (RRAA), 2000. The Act extended the scope of the 1976 Race Relations Act by covering public bodies which had been previously exempt and making it unlawful for public authorities to discriminate in carrying out any of their functions. While this Act, like previous race relations legislation, prohibited unlawful discrimination, a new approach was also evident. For the first time, a general statutory duty was placed on all public authorities, and specific duties on some authorities, to eliminate racial discrimination (including indirect discrimination), promote good race relations and facilitate equality of opportunity. The Act gave the Commission for Racial Equality (CRE) the power to develop a statutory code of practice and provide guidance to public authorities on how to meet the general duty and any specific duties introduced by the Home Secretary. By enjoining public bodies in this way to develop policies and plans which promote racial equality, the RRAA adopted a very different approach to that embodied in previous race relations legislation: public authorities were now being required to take a pro-active stance to racial equality and thus take the lead in eliminating racial discrimination, promoting good race relations and facilitating equal opportunities.

While the colour blind strategies were not very successful in promoting race equality, the race relations legislation introduced in $\mathbf{2 0 0 0}$ proved more effective, at least for a time. Under the Race Relations (Amendment) Act, universities were obliged to develop race equality policies and action plans by May 2002. These policies and action plans needed to meet both the general and specific duties laid down by the legislation. The specific duties for HEls were: 
- Prepare and maintain a written race equality policy and implementation plan;

- Within the policy and plan assess the impact of institutional policies on staff and students from different racial groups;

- Within the policy and plan monitor the applications, admissions and progression of students;

- Within the policy and plan monitor the recruitment and development of staff;

- Within the policy and plan set out arrangements for publishing the race equality policy and the results of monitoring impact assessments and reviews.

What is interesting about these specific duties is what they prioritise. They do not, unlike the AntiRacist Toolkit produced by Leeds University (Turney et al 2002), focus on teaching and research, but on widening participation and equal opportunities (Sharma 2004) The colour blind widening participation and equal opportunity policies may have, as we have seen, bypassed minorities, but targeted policies it was hoped would make a difference.

University race equality policies and action plans were subsequently audited in 2003 and 2004. While the initial audit found more than a third of higher education institutions (HEIs) had not satisfactorily met their statutory obligations (John, 2003), subsequent audits were more upbeat and pointed to the considerable progress travelled by the majority of HEIs (OPM 2004a and b). Given that a report published a mere 5 years earlier indicated that only a few HEls had a race equality policy at all, such an upbeat position is understandable. However, it should be noted that these audits were desk based and that the reality on the ground might be very different.

So what can we provisionally conclude? Colour blind government strategies to widen participation and promote equal opportunities seem to have had minimal impact in combating race inequality in the period that we have examined. By contrast, the more targeted Race Relations (Amendment) Act seems to have had more impact, at least in the sense of generating race equality policies and plans.

We need to be circumspect, however. Even when legislation had insisted on the production of race equality policies and action plans and guidance had been provided to aid the production process, the requisite policies and action plans were often initially lacking, and significant pressure had to be exerted to ensure minimal compliance (John, 2003). What is more, when (some of) those institutions that had produced exemplary policies were followed up eighteen months to two years later, those Institutions had generally done very little to translate their first class policy into meaningful action (John 2005: 593-94). The reviews that we have drawn upon here have perforce been focused on documents but there is a danger being too reliant on documents. This is that we confuse what is written in strategic and policy documents with what actually happens in institutions. Since strategic and policy documents often serve as the public face of the university, an inordinate amount of time can go into getting them just right. This can mean that writing documents and having good policies becomes a substitute for action: as an interviewee in one study (Ahmed, 2012) puts it, "you end up doing the document rather than doing the doing"' (Ahmed, 2007)..

Conscious of the dangers of reliance on official documents, I conducted an ethnographic investigation of one university in the decade following the publication of the Macpherson report (Pilkington, 2011). A colleague has subsequently extended the investigation to 2013 (Crofts, 2013). The university is a new university in Central England and will be identified as Midshire University. 
What is immediately apparent is that at different times more or less attention has been placed on race equality. At certain points, the university has made a serious effort to address the issue of race equality. At other times, the issue has not been on the institution's radar. The development of equal opportunity policies from 1989 onwards eventually led to the development of action plans for different strands of equality. A race equality plan was devised between 1992 and 1994 . This was updated and launched in 1996 and can be considered to be a relatively advanced policy at this time. Within an extraordinarily short time, however, the policy had been forgotten. Indeed the subsequent requirement under the Race Relations (Amendment) Act to develop by May 2002 a race equality policy and action plan was not appropriately met. The university was subsequently required to resubmit its policy and action plan to HEFCE within a limited time period. This provided an opportunity for race equality champions within the university to develop a robust policy and action plan and persuade senior management to put in place appropriate resources to support the policy and plan. It is noteworthy that what prompted the recovery was not the race relations legislation per se but the independent review which indicated the university was non-compliant.

Race equality subsequently had a higher priority within the university. New governance arrangements and the arrival of two equality and diversity officers in 2004 subsequently gave equality and diversity generally and race in particular a higher profile. And there is no doubt that for some years significant progress was made. The conditions facilitating this included (for a period) external pressure on the university, support from some key senior staff and the presence of highly effective equality and diversity officers.

\section{The declining salience of race equality}

The middle of the first decade of the new millennium represented the university's high point in terms of addressing race equality. Since then external pressure from the government has ineluctably declined (Feldman, 2012). Although lip service continues to be paid in government pronouncements and some strategies to race equality and ethnic diversity, other government agendas prompted by concerns over increasing net migration, disorder and terrorism subsequently marginalised one concerned with race equality. This is evident in relation to the way new legislation introduced by the Labour government in 2010 has been subsequently implemented.

The Equality Act 2010 extended the general duties (now labelled the public sector equality duty), initially identified in the race relations legislation, to different strands of equality, with the Equality and Human Rights Commission (EHRC), a body that had been set up earlier to replace a series of bodies focused on distinct strands of equality, being charged with having an enforcement role. Over time, however, and especially since the Coalition government (2010) and subsequent Conservative government (2015) took power, the requirements embodied in the legislation have been eroded. Thus the specific duties, enshrined in statutory codes of practice, including the requirement to have in place an equality action plan and conduct equality impact assessments have been replaced by the need, on which there is merely guidance, to publish limited data and set one or more objectives. And at the same time, the red tape challenge and the significant cut in funding for the EHRC signal that racial equality is sliding down the government's agenda.

\section{The period ic emergence in policy discourse of race equality}


Inevitably I have been constructing a narrative in this chapter and it is a narrative that seeks to present a coherent story. Race equality and ethnic diversity have been deprioritised as other governmental agendas rise to prominence. In the process the external pressure on the university sector has waned with the result that there is a very real danger that the gains that have been made will not be maintained let alone built upon. It is important, however, not to overstate my case or assume complete consistency in the government's approach. What should be noted in this context is the continuing concern of some parts of the machinery of government with racial equality throughout the period I have been discussing.

A seeming case in point is the Ethnicity and Degree Attainment Project. This arose out of the findings of a research study published in January, 2007 which demonstrated that, even after controlling for a plethora of contributory factors, minority ethnic status generally had an adverse effect on degree attainment (Broecke \& Nicholls, 2007). The findings prompted the Department for Innovation, Universities and Skills (DIUS) and the English and Welsh funding councils to commission the Higher Education Academy and Equality Challenge Unit to undertake a project to explore possible causes and practical responses. The project culminated in a report that waslaunched at a conference in January, 2008. On possible causes, the report concluded: 'The causes of degree attainment variation....were found to be unlikely to be reducible to single, knowable fact ors' and on practical responses, the report made two key recommendations: 'There is a need to ensure that the valuable information gained from data sources... are used as a means of reflective institutional analysis and action planning' and 'HEls need to implement systems that can evaluate, review and design teaching, learning and assessment activities in light of data on degree attainment variation' (Higher Education Academy, 2008: 3-4). What was disturbing as an attendee at the conference was the sense of déjà vu. The audience comprised academics rather than administrators, but the key recommendations and much of the discussion were not dissimilar to those at conferences six years earlier designed to prepare universities to meet their duties under the Race Relations (Amendment) Act. While the report itself does acknowledge that 'higher education institutions are legally required to gather data...and then take action against any adverse findings' (Higher Education Academy, 2008: 13), the recommendations were presented to the conference as though they were new. It is both remarkable and revealing how quickly previous initiatives had been forgotten. It is remarkable because of the short time that had elapsed since universities were required to demonstrate how they were meeting the specific duty 'to monitor the applications, admissions and progression of students by racial group'. It is revealing because it raises serious doubts about whether the sector is any longer under pressure to take race seriously and, in the seeming absence of such pressure, whether it is likely to take any sustained action to promote race equality and ethnic diversity. In this context it is revealing to note that less than half the access agreements, which universities are obliged to produce for formal approval by the Office for Fair Access, 'address the persistent gap in attainment rates for students from different ethnic minority groups' and this despite the fact that this issue is supposedly central to 'the national strategy for access and student success' (OFFA, 2016: 3). It is difficult not to conclude that this episode exemplifies lip service being paid to racial equality and ethnic diversity.

This judgement is confirmed in my view by successive funding letters from the government to HEFCE (2016) which consistently identify widening participation as a priority but at the same time periodically acknowledge the continuing failure of elite universities to increase significantly their enrolment of students from disadvantaged backgrounds. The government's most recent proposal to 
improve opportunities for students from disadvantaged groups (which it is recognised incorporate many BME groups) is contained in the HE White paper (DfBIS, 2016). The emphasis yet again is on the obligation for HEIs to publish data! As the ECU (2016) optimistically puts it, 'HEls will be required to publish data on application, offer and progression by ethnicity, gender and socioeconomic background. Provision of this information, along with overall participation rates, continuation rates, degree attainment and outcome and employment outcomes will help the sector to understand the barriers that exist - and put in place measures to overcome disadvantage'. While it would be an exaggeration to say that equality and diversity, and concomitantly race equality and ethnic diversity, have completely disappeared as policy objectives, the contrast between the policy initiatives at the beginning of the century which demanded the production of action plans and this latest initiative which merely 'nudge[s] universities into making the right choices and reaching out in the right ways' as part of 'our ambitious (sic) "2020 agenda" for BME communities' (Cameron, 2016: 2-3) could not be more palpable.

The consequence of the declining salience of race equality in government pronouncements and the decreasing pressure on universities to promote race equality has been felt graphically at Midshire University. At the university, this initially entailed increasing resistance to an equality and diversity agenda, but eventually led to the disappearance of any dedicated committees or equality and diversity officers (Crofts, 2013). This development was justified in terms of mainstreaming but has in fact entailed a reversal of the progress made in the preceding years to meet the general and specific duties of the race relations legislation.

What is remarkable is that at the same time, evidence of racial disadvantage remains stubbornly persistent. In my study, I found the following: persistent ethnic differentials in the student experience that adversely impact on BME students and point to possible indirect discrimination; ethnic differentials in staff recruitment that adversely impact on Black and Asian applicants and point to possible indirect discrimination;(some) minority ethnic staff subject to racism and (some) White staff cynical about political correctness; an overwhelmingly White senior staff team, with no evident efforts to transform this situation; low priority given to the implementation of a race equality action plan; few staff skilled in intercultural issues; many staff not trained in equality and diversity; and few efforts made to consult Black and Asian communities.

We cannot of course generalise from this case study to the sector as a whole. Nonetheless, what we have found at Midshire University resonates with findings elsewhere (Turney et al. 2002; Bhattacharya 2002; Major 2002; Bhopal, 2015) and points to what one author has called 'the sheer weight of Whiteness' (Back, 2004: 1). It is impossible to comprehend the persistence of racial disadvantage and the failure to combat this without recognising 'how deeply rooted Whiteness is throughout the ... system' (Gillborn 2008: 9). While minority ethnic staff are typically conscious of this, often for White staff (including White researchers) '... the Whiteness of the institution goes unnoticed and is rationalised into a day-to-day perception of normality' (Law, Phillips, and Turney 2004, 97). It is crucial therefore that we are reflexive and do not let "the "whiteness" of the academy ... .go unnoticed and uncommented' (Clegg, Parr, and Wan, 2003, 164; Frankenberg, 2004).

\section{Continuing racial disadvantage in the HE sector: BME staff and students}

Research continues to demonstrate that individuals from minority ethnic communities disproportionately experience adverse outcomes (Grove, 2015)). While there is some variability by 
ethnic group since BMEs are by no means a homogeneous category, BME staff and students experience considerable disadvantage. BME academic staff are more likely to be on fixed term contracts, continue to experience significant disadvantage in career progression, especially in gaining access to the senior ranks of university management, and there remains an ethnic pay gap virtually 2 decades after the publication of the Macpherson report (Leathwood et al, 2009; ECU, 2011; Ratcliffe and Shaw, 2014)). Indeed a recent report based on interviews with BME staff is sceptical that much has changed in the last 20 years: the vast majority continue to experience subtle racism and feel outsiders in the White space of the Academy (Bhopal, 2015). Meanwhile BME students continue to be less likely to be enrolled at elite universities (UCAS, 2016) and awarded good honours degrees even when prior attainment and socio-economic status have been taken into account (Broeke \& Nicholls, 2007; HEA, 2008), and to experience lower retention rates and progression rates from undergraduate study to both employment and postgraduate study (OFFA, 2016; HECE, 2016

). In this context it is not altogether surprising that they express significantly less satisfaction with their university experience (Havergal, 2016). And yet, despite this evidence of the remarkable persistence in racial disadvantage, universities are extraordinarily complacent.

\section{Legislation and equality}

This complacency partly stems from the dominance in the academy and much of society of a liberal perspective on equality. We can distinguish two broad perspectives on equality - liberal and radical. The first is concerned to promote fair or like treatment and to this end seeks to devise 'fair procedures' so that everybody, regardless of race, receives the same treatment and 'justice is seen to be done' (Noon \& Blyton, 1997: 177). The emphasis in this approach is upon sanctions against any form of racially discriminatory behaviour. The second 'represents a more radical approach since it suggests that policy makers should be concerned with the outcome, rather than the process, and should therefore be seeking to ensure a fair distribution of rewards' (Noon \& Blyton, 1997: 182). To treat everybody the same is, in this view, to ignore pertinent differences between people and does little to eradicate disadvantage which stems from discrimination in the past and current institutional practices which result in indirect discrimination. To ensure fair outcomes - such as an ethnically balanced workforce - what are needed are not merely sanctions against racial discrimination but measures which entail positive discrimination i.e. preferential treatment of disadvantaged groups.

The liberal perspective has primarily informed legislation and policies in the UK. Take the 1976 Race Relations Act. The emphasis was on like treatment, with the law enabling sanctions to be deployed against those found to be guilty of racial discrimination. Positive discrimination was not permitted and the 'overall thrust was individualist' with the legal process demanding proof that 'individual members of racial groups [had] suffered discrimination' before racial discrimination could be established and sanctions deployed (Parekh, 1996: 18). Nonetheless, the Act did move beyond like treatment in two respects. Firstly, the recognition that discrimination took indirect forms entailed an acknowledgement that practices, which treated people in the same way, could disproportionately and adversely effect some groups more than others. Secondly, organisations were encouraged under the Act to counter the effects of past discrimination and redress the under representation of 
minority groups by developing positive action programmes. The rationale for such programmes, which included targeted advertising campaigns and training courses, was 'to encourage the previously disadvantaged to the starting gate for jobs, promotion and other opportunities' (Blakemore \& Drake, 1996: 12). Once at the starting gate, however, and in contrast to the situation which prevailed in the United States from the mid 1960s to (at least) the late 1980s and has developed in Northern Ireland since 1989 (Noon \& Blyton, 1997), no preferential treatment was permitted and legally enforceable quotas for disadvantaged groups were expressly disallowed.

The government's major response to the Macpherson report was, as we have argued above, a legislative initiative, the Race Relations (Amendment) Act (RRAA), 2000. While this Act, like previous race relations legislation, was partly informed by the liberal perspective and thus prohibited unlawful discrimination, the Act was also informed by the radical perspective and adopted an approach that required public bodies to take the lead in eliminating racial discrimination, promoting good race relations and facilitating equal opportunities. To this end universities were required to produce race equality action plans in order to facilitate fair outcomes. Unfortunately, many of the key players in the university sector adopt a liberal perspective on equality and believe fair procedures are what is important (Deem et al, 2005; Crofts, 2013). They see themselves as liberal and believe existing policies ensure fairness and in the process ignore adverse outcomes and do not see combating racial/ethnic inequalities as a priority. This points in my view to the sheer weight of whiteness (if not institutional racism) which will remain intact unless significant pressure is placed on universities to change.

\section{What is to be done?}

Universities will not be able to promote race equality and combat the adverse outcomes faced by BME staff and students unless they see it as their responsibility to take ameliorative action. No truck should be given to a deficit model which explains away the racial disadvantage faced by BME staff and students evidenced above. While there may be no easy answers, the key starting point is for universities to ask what they can do to ensure more equitable outcomes. Do we have forums which enable us effectively to consult with BME staff and students? What measures need to be taken to ensure diversity in leadership? Are there unconscious biases in selection and promotion boards at play which need to be dismantled? And so on.

We can distinguish two ideal typical approaches.

The first is sceptical as to whether universities will as a matter of course promote race equality and ethnic diversity. External pressure in this view is vital to facilitate change. To this end, the first approach believes that legislation and the enforcement of that legislation are crucial; sees a need for there to be a focus on race equality rather than equality in general; adopts a radical perspective on equality; identifies the need for action plans with clear targets which are regularly audited; requires publication of time series and comparative data to ensure transparency; and identifies the need for periodic inspection by an independent body.

The second approach is very different in visualising universities as having an inherent interest in promoting race equality and ethnic diversity in a highly competitive global marketplace where universities compete for students and require a diverse workforce. Legislation compelling universities to act in particular ways, according to this approach, is less effective than nudges and 
persuasion to remind them to utilise appropriate data to identify and dismantle barriers to equal opportunities for individuals from disadvantaged groups. Rather than imposing mandatory requirements, it is deemed preferable for universities to set their own objectives in the light of their own particular circumstances, Independent bodies ideally will identify good practice and disseminate it widely to the sector and even give awards to those universities who manifest good practice. In the process, universities will not merely comply with external demands but steadily transform themselves.

While neither of these two approaches can be found in their pure form in the real world, there is little doubt that the period we have examined has witnessed the transition from an approach close to the first ideal type to an approach close to the second. Both approaches have some merits. It is probably evident that I have greater sympathy for the first approach and thus welcome EHRC's recent call for a comprehensive race equality strategy (EHRC, 2016). Adoption of this approach following publication of the Macpherson report did entail some progressive change in the sector and its abandonment prevented this being sustained both at the sectoral level and at Midshire University. It would be utopian to anticipate the return of this approach in the near future. And the second approach can entail progressive change in some universities, as evidenced by those who have met the requirements for a bronze award of the race equality charter.

\section{Bibliography}

Ahmed, S (2007) "'You end up doing the document rather than doing the doing": Diversity, Race Equality and the Politics of Documentation' Ethnic and Racial Studies, Vol 30, No 2, pages 235-256.

Ahmed, S. (2012) On Being Included: Racism and Diversity in Institutional Life, London, Duke University Press.

Aimhigher (2006) A Review of Black and Minority Ethnic Participation in Higher Education, www.aimhigher.ac.uk/sites/practitioner/resources/Conf\%20Summary\%20report\% (last accessed 20/11/11)

Bhattacharya, G. (2002) 'The Unwritten Rules of the Game: Imagine Working in a Place Where the Rules Aren't the Same for Everyone' The Guardian, January 15, www.guardian.co.uk/education/2002/jan/15/raceineducation. race1 (last accessed 24/03/13).

Bhopal, K. (2015) The Experiences of Black AND Minority Ethnic Academics, A Comparative Study of the Unequal Academy, London, Routledge

Blakemore, K. \& Drake, R. (1996) Understanding Equal Opportunity Policies, London, Prentice Hall.

Broecke, S., Nicholls, T. (2007) Ethnicity and Degree Attainment, Research report RW92, London, Department for Education and Skills. 
Cameron, D (2016) 'Watch out universities; I'm bringing the fight for equality to you', https://www.gov.uk/government/speeches/watch-out-universities-im-bringing-the-fight-forequality-in-britain-to-you-article-by-david-cameron (last accessed 29/06/16)

Carter, J., Fenton, J. \& Modood, T. (1999) Ethnicity and Employment in Higher Education, London, Policy Studies Institute.

Clegg, S., Parr, S. \& Wan, S. (2003) 'Racialising Discourses in Higher Education', Teaching in Higher Education, Vol.8, No.2, pages $155-168$

Connor, H., Tyers, C. Modood, T. (2004) Why the Difference? A Close Look at Higher Education Minority Ethnic Students and Graduates, Research Report RR448, London, Department for Education and Skills.

Crofts, M. (2013) The Impact of the Public Sector Equality Duties on Higher Education: A Case Study, Northampton, University of Northampton.

Deem, R., Morley, L. Tlili, A. (2005) Negotiating Equity in Higher Education Institutions, www.hefce.ac.uk/pubs/redreports/2005/rd10_05/rd10_05doc (last accessed 30/05/10).

Department for Business, Innovation and Skills (2016) Higher Education: Success as a Knowledge Economy - White Paper, https://www.gov.uk/government/publications/higher-education-successas-a-knowledge-economy-white-paper (last accessed 28/06/16)

Equality Challenge Unit (ECU) (2011) Experience of Black and Minority Ethnic Staff in Higher Education in England, London, ECU.

ECU (2016) 'ECU Responds to White Paper', http://www.ecu.ac.uk/news/ecu-responds-to-he-whitepaper/ (last accessed 28/06/16)

Equality and Human Rights Commission (2016) Healing a Divided Britain: The Need for $a$ Cpmprehensive Race Equality Strategy, https://www.equalityhumanrights.com/en/publicationdownload/healing-divided-britain-need-comprehensive-race-equality-strategy (last accessed 16/09/16).

Feldman, S (2012) ‘Opportunity Blocks', Times higher Education, 29 November.

Frankenberg, R. (2004) 'On Unsteady Ground: Crafting and Engaging in the Critical Study of Whiteness' in Bulmer, M. and Solomos, J. (eds.) Researching Race and Racism, London, Routledge, pages 104-118. 
Gillborn, D. (2008) Racism and Education, London, Routledge.

Grove, J (2015) 'Black and Ethnic Minorities Still have Mountains to Climb in Higher Education', Times Higher Education, 5 November.

Hansard, (1999) 'Stephen Lawrence Inquiry', 24 February www.publications. parliament.uk/pa/cm199899/cmhansard/vo990224/debtext/90224-21.htm. (last accessed 23/08/12)

Havergal, C. (2016) ‘BME Students are not Satisfied', Times Higher Education, 9 June.

Higher Education Academy (2008) Ethnicity, Gender and Degree Attainment Project: Final Report, London, ECU.

Higher Education Funding Council for England (HEFCE), (2005a) Equal Opportunities and Diversity for Staff in Higher Education, http://www.hefce.ac.uk/pubs/hefce/2005/05_19/05.19.pdf (last accessed 29/05/12).

HEFCE (2005b) HEFCE Race Equality Scheme, http://www.hefce.ac.uk/pubs/hefce/2005/05 04/ (last accessed 26/0616)

HEFCE (2007) Rewarding and Developing Staff in Higher Education, www.hefce.ac.uk/lgm/hr/reward/ (last accessed 21/08/12)

HEFCE (2016) Grant Letter from the secretary of State to HEFCE, (http://www.hefce.ac.uk/funding/govletter/ (last accessed 27/06/16)

Jacobs, S. \& Hai, J. (2002) 'Issues and Dilemmas: "Race” in Higher Education Teaching Practices' in F. Anthias and C. Lloyd (eds) Rethinking Anti-Racisms, London, Routledge.

John, G. (2003) Review of Race Equality Policies and Action Plans in HEFCE-funded Higher Education Institutions, www.hefce.ac.uk/lgm/divers/ecu (last accessed 30/10/12)

John, G. (2005) Taking a Stand, Manchester, Gus John Partnership.

Law, I. (2003) 'University Teaching in Ethnicity and Racism Studies: Context, Content and Commitment', Ethnic and RacialStudies, Vol.26, No.3.

Law, I., Phillips, D. Turney, L. (2004) (eds.) Institutional Racism in Higher Education, Stoke on Trent, Trentham Books. 
Leathwood, C., Maylor, U. and Moreau, M.P. (2009) The Experience of Staff Working in Higher Education, London, Equality Challenge Unit.

MacPherson, W (1999) The Stephen Lawrence Inquiry: Report of an Inquiry by Sir William Macpherson of Cluny, London, HMSO.

Major, L. (2002) 'Incredible Islands', The Guardian, January 15, www.guardian.co.uk/education/2002/jan/15/raceineducation. race1 (last accessed 27/06/16)

Neal, S (1998) The Making of Equal Opportunity Policies in Universities, Buckingham, SRHE/Open University Press.

Noon, M. \& Blyton, P (1997) The Realities of Work, London, Macmillan.

Office for fair Access (OFFA) (2016) 'Topic briefing: BME Students', https://www.offa.org.uk/universities-and-colleges/guidance-and-useful-information/topicbriefings/offa-topic-briefing-bme-students/ (last accessed 28/06/16)

HEFCE (2016) Differences in Employment Outcomes: Comparison of 2008-09 and 2010-11 first degree graduates, http://www.hefce.ac.uk/pubs/year/2016/201618 (last accessed 15/09/16).

OPM [Office of Public Management] (2004a) Assessment of Race Equality Policies and Plans in HEFCE-funded HEIs, www.hefce.ac.uk/Pubs/rdreports/2004/rd09_04/ (last accessed on 01/12/11).

OPM [Office of Public Management] (2004b) Review of Progress in Race Equality, www.hefce.ac.uk/Pubs/rdreports/2004/rd09_04/ (last accessed on 01/12/11)

Pilkington, A (2008) 'From Institutional Racism to Community Cohesion: The Changing Nature of Racial Discourse', Sociological Research Online, Vol.13, No.3, http://www.socresonline.org.uk/13/3/6.html (last accessed 27/06/16).

Pilkington, A. (2011) Institutional Racism in the Academy: A UK Case Study, Stoke on Trent, Trentham Books.

Pilkington, A (2014) 'The Sheer Weight of Whiteness in The Academy: A UK Case Study' in R. Race and V. Lander (eds) Advancing Race and Ethnicity in Education, Basingstoke, Palgrave. 
Ratcliffe, R amd Shaw, C. 'White males Monoplise Best paid Jobs in UK Universities, Report Shows', https://www.theguardian.com/higher-education-network/2014/nov/18/-sp-white-malesmonopolise-highest-paid-jobs-uk-universities (last accessed 27/06/16)

Reay, D., David, M. Ball, S. (2005) Degrees of Choice, Stoke on Trent, Trentham Books.

Sanders, P. (1998) 'Tackling Racial Discrimination' in Blackstone, T., Parekh, B., Sanders, P. (eds.) Race Relations in Britain, London, Routledge, pages 36-52.

Sharma, S. (2004) 'Transforming the Curriculum' in Law, I., Phillips, D., Turney, L (eds.) Institutional Racism in Higher Education, Stoke on Trent, Trentham Books, pages 105-118.

Thomas, L., May, H., Houston, M., Knox, J.,, Lee, M., Osborne, M' „, Pudner, H., and Trotman, C. (2005) From the Margins to the Mainstream, London, Universities UK.

Turney, L., Law, I. \& Phillips, D. (2002) Institutional Racism in Higher Education Toolkit Project: Building the Anti-Racist HEI, www.leeds.ac.uk/cers/toolkit/toolkit.htm. (last accessed 16/08/2005).

UCAS (2016) 'UCAS publishes first equality reports fro individual universities' https://www.ucas.com/corporate/news-and-key-documents/news/ucas-publishes-first-equalityreports-individual-universities (last accessed 29/06/16) 